and special arrangements are planned for educationists and writers of school and university text-books. British books cannot, however, be purchased by Germans. The Control Commission has officially approved a scheme, put forward by the Agency for Intellectual Relief in Germany, under which the Agency will establish lending libraries for British books in key-centres of the British zone. The first library, containing some four thousand books, is being opened in Hamburg. Once the libraries have been established, German committees in each town will take over the management; it is expected that current expenditure in Germany will be covered by the borrowers' fees. A list of books needed, based on suggestions by German readers, has been prepared. Contributions are solicited towards the cost of books that must be bought; cheques should be sent to the honorary treasurer of the Agency for Intellectual Relief in Germany, C. P. Kininmonth, 4 Chapel Row, Wheeler End, High Wycombe, Bucks. Information relating to the scheme can be obtained from the Agency for Intellectual Relief in Germany, Foreign Office, German Section, 48 Prince's Gardens, London, S.W.7.

\section{Import of Scientific and Technical Books}

Replying to a question in the House of Commons, the President of the Board of Trade stated that he is prepared to consider the issue of licences for limited additional imports of technical and scientific books in English from certain European countries. Similar books in foreign languages from non-English speaking countries are licensed freely.

\section{German Hydrographic Institute, Hamburg}

Tre first annual report of the German Hydrographic Institute, Hamburg, consists of a 64-page booklet both in German and English (the former language being that of the official text). It gives a good account of the provision which has been made in Germany since the War for the performance of the various tasks formerly undertaken by the organisation which was the German analogue of the Hydrographic Department of the British Admiralty. Along with that account, which tells of work to do with marine surveying, the making and printing of nautical charts, the issue of nautical books, the testing of compasses, the observation and publication of magnetic values, the issue of time signals, and with many other matters concerning which information is needed by mariners and required by the naval side of the Allied occupying authority, there is substantial information bearing upon the present state of German oceanography.

Before the War, the science of oceanography had numerous practitioners in Germany, and, in addition to the two well-known and very large organisations devoted to its furtherance, there were several small scientific bodies of repute which worked in this sphere. The report records how plans were laid for the em. ployment of about one-fifth of the large number of oceanographers to work upon tasks which should serve the interests of, and meet the needs of, that rump organisation which-it was approved by the Allied Control Council-had to be set up to carry out essential hydrographical duties in German waters. These scientific workers ultimately became Section 2 of the Institute which is the subject of the report. This, established initially by the British naval authorities, is now under the governance of a quadripartite board of four directors, functions in Hamburg, and is 'managed' by the British director, who is a captain in the Royal Navy. Considerable information is given concerning reports which have been written by various German marine scientific workers since the capitulation, and it is expected soon to start upon the issue of a periodical wherein such reports will be printed for circulation.

\section{National Foundry College}

THe National Foundry College has been established and its board of governors nominated by the Minister of Education. The College will be housed in, and work closely in conjunction with, the Wolverhampton and Staffordshire Technical College. The board of governors is eharged with the responsibility for providing national facilities for foundry education and research, in the form of full-time courses, vacation courses, refresher courses, and the like, and also for providing regional and local facilities for full-time, part-time day and evening courses, to cover the whole range of foundry education. Its first task will be the re-establishment of the full-time diploma course which was the main feature of the predecessor of the College, the British Foundry School, during 1935-39. This course will normally run for an academic year, and the first session opens on January 5. The course will cover the whole of the foundry industry, ferrous and non-ferrous, including grey, white and chilled iron castings, malleable castings, steel castings, and castings in non-ferrous metals, such as alloys of copper, tin, zine, nickel, aluminium and magnesium. The diploma awarded to successful students will be endorsed by the Ministry of Educa. tion. There is no upper age limit for admission; a minimum of one year's practical experience in at least one branch of the industry will be required, together with a Higher National Certificate or a university degree, preferably in metallurgy or engineering, or a grade of membership obtained by examination of a professional institution in engineering, metallurgy or chemistry. Mr. J. Bamford, who was in charge of the British Foundry School during 1935-39, and who has since held important managerial appointments in the industry, has been appointed head of the National Foundry College.

\section{Abstracts on Powder Metallurgy}

Hrthento available in private circulation only, Metal Powder Report is now issued at an annual subscription of $£ 37 s .6 d$. The report is a sixteen-page monthly abstract journal dealing solely with the production, treatment and use of metal powders, under the joint editorship of W. D. Jones and R. A. Hetzig. The use of such products in electronics, the metallization of glass and ceramic materials, iron driving bands, porous aluminium-base bearings, electrical contacts, magnetic materials, sintered plates for batteries, sparking plugs, and stainless steel powders for paints and lacquers, all of which are mentioned in the issues for September and October 1947, will give an indication of the surprising breadth of interest of this very new branch of metallurgy. All concerned with powder metallurgy in any of its aspects will find this publication of real use. It is available from Powder Metallurgy, Ltd., Commonwealth House, 1-19 New Oxford Street, London, W.C.1.

\section{Biological Abstracts}

A NEW section of Biological Abstracts (University of Pennsylvania, Philadelphia) will be published as from January 1948. The section ( $J$-Abstracts of 
Cereals and Cereal Products) will appear monthly except during the four summer months, when it will be bi-monthly. It will bring together abstracts of the entire technological and scientific literature on the cereal grains-wheat, corn, rye, oats and barley -and on all other grains such as soya bean, cottonseed, buckwheat, etc., utilized by the milling and food industries. It will include contributions on plant breeding, cultural practices, varieties, soil and weather relations of the crops; physiology, diseases, insect pests ; storage of grain and flour ; milling machinery and techniques; plant sanitation; baking and nutritional studies on diets in which cereal and related products are important components; biochemistry of cereals and cereal products ; enzymes ; and industrial microbiology in so far as it affects the cereals and their products.

\section{U.N.E.S.C.O. Fellowships}

The first two of the fellowships placed at the disposal of U.N.E.S.C.O. by the American Chemical Society have been awarded to men of science from Czechoslovakia. The successful candidates are Dr. Milos Hudlicky, assistant at the Institute of Organic Chemistry at Prague, and Dr. Ivan Vavruch, assistant at the Research Institute of the Czechoslovalk Sugar Institute, also in Prague. It is hoped that both the new fellows will be able to take up their appointments early in 1948. One of the fellowships offered by the Belgian Ministry of Education under the same U.N.E.S.C.O. scheme has been awarded to $\mathrm{Mr}$. Charalambos Vacalopoulos, who is studying international relations in Brussels. The organisation of a programme of fellowships of this kind is one of the most important of the aims of U.N.E.S.C.O., as it is designed to make it possible for scientific workers, teachers and others from war-devastated countries who were cut off from the outside world during the War to be made aequainted with the most recent developments in the field of their specialization.

\section{Conference on Ethics and Science}

IN July last year the British Social Hygiene Council held a conference on "The Problems of Communal Life: the Ethical and Scientific Approach", which proved so successful that the Council was asked to arrange something similar this year. In response to this request, a one-day conference has been arranged for December 4, and will take place in the Livingstone Hall, Tothill Street, Westminster, S.W.1. Its main theme will be "Society and the Individual", which will be considered under two headings, namely, "The Values Society sets upon the Individual", and "The Values the Individual sets before Himself". Ample time will be allowed for discussion at the end of both the morning and afternoon sessions and at an open meeting in the evening. Once again the aim of the Conference is to effect, in some measure, a synthesis between the spiritual and the scientific interpretations of life. The chair will be taken by Prof. Winifred Cullis and Dr. E. B. Strauss, and the speakers include Mr. L. J. F. Brimble, Father Leycester King, Canon Marcus Knight, Dr. E. H. Larkin, Mr. J. MackayMure, Dr. Mary Smith, Mrs. Joan B. Thompson, Mr. Kenneth Walker, and Mr. R. Weatherall. Further information and tickets (members of the Council 2s. $6 d$, others $3 s .6 d$.) can be obtained from the British Social Hygiene Council, Tavistock House North, Tavistock Square, London, W.C.I.

\section{Royal Society of Edinburgh : Officers for 1947-48}

Aт a statutory meeting of the Royal Society of Edinburgh, held on October 27, the following officers and members of council were elected : President, Sir William Wright Smith ; Vice-Presidents, Lord Cooper, Prof. J. W. Heslop Harrison, Prof. W. M. H. Greaves, Lieut.-Colonel W. F. Harvey, Prof. James P. Kendall, Sir Ernest Wedderburn; General Secretary, Dr. J. E. Richey; Secretaries to Ordinary Meetings, Prof. Arthur Holmes, Prof. E. T. Copson; Treasurer, A. W. Young; Curator of Library and Museum, Dr. John E. Mackenzie; Ordinary Members of Council, Prof. E. P. Cathcart, Prof. A. Gray, Dr. J. R. Greig, Dr. W. A. Harwood, Prof. C. M. Yonge, Prof. A. D. Hobson, Dr. W. O. Kermack, Dr. John Weir, Prof. J. H. Gaddum, Prof. G. D. Preston, Prof. S. J. Watson, R. Ll. Gwilt.

\section{Announcements}

THE Hanbury Gold Medal for 1947 of the Pharmaceutical Society of Great Britain was presented on November 13 to Dr. Hans Flück, professor of pharmacognosy in the Faculty of Pharmacy of the Foderal Technical Institute, Zurich.

THE Pedler Lecture of the Chemical Society will be given by Sir Ian Heilbron, professor of organic chemistry, Imperial College of Science and Technology, London, at the Society's rooms on December 4 at 7.30 p.m. He will speak on "Recent Developments in the Vitamin A Field".

Dr. W. J. Kearton, senior lecturer in mechanical engineering in the University of Liverpool, has been appointed to the Harrison chair of mechanical engineering in the University.

MR. JoHN WILSON, director of research to the British Rubber Producers' Research Association, has been appointed director of research to the British Rayon Research Association.

Srr Chartess Eulrs, president and chairman of Council of the British Coal Utilization Research Association, has announced the following new titles in respect of the directorate of the Association : Dr. D. T. A. Townend, director-general; Dr. D. H. Bangham, director of research laboratories; Dr. E. G. Ritchie, director of engineering laboratories; Mr. J. S. Hales, director of domestic appliance laboratories; Mr. H. T. Hathaway, secretary and finance officer.

THe film "Nagana", introduced by Dr. P. J. du Toit at a meeting held at the London School of Hygiene and Tropical Medicine to discuss "D.D.T. and the Aeroplane in the Control of the Tsetse Fly and Trypanosomiasis in South Africa" (see Nature, October 11, p. 485), is now at the South African Scientific Liaison Office, 39 Prince's Gate, London, S.W.7, and is available on loan to scientific bodies wishing to show it. It is a $16-\mathrm{mm}$. colour film with sound-track.

THe Boron Agricultural Bureau announces that its work will be brought to a close at the end of December 1947. Its comprehensive collection of literature on the uses and functions of boron in agriculture, which has been assembled during the last eleven years, will be presented to the library of the Rothamsted Experimental Station, where it will be available for consultation. 